\title{
МЕТОДОЛОГІЯ ФОРМУВАННЯ ГРУПОВИХ ОПЕРАЦІЙ ПРИ ПРОЕКТУВАННІ ГВС
}

\begin{abstract}
Вступ
Проектування сучасних гнучких виробничих систем (ГВС) здійснюється на основі використання параметрів тієї номенклатури об'єктів виробництва $(\mathrm{OB})$, випуск яких повинна забезпечити дана система. Однак, важко оцінити, як зміниться номенклатура цих об'єктів найближчим часом. Не виключено, що в умовах швидкої зміни номеклатури продукції пройдуть суттеві зміни і конструктивних характеристик ОВ, які неможливо спрогнозувати наперед. В результаті побудована ГВС може виявитися нездатною виконувати свої функції, або буде виконувати їх не в повному обсязі.

Тому, в сучасних умовах розвитку виробництва, важливо вже на стадії проектування ГВС закласти таку ступінь гнучкості технології і комплексу обладнання для виготовлення ОВ, які б дозволили ГВС змінювати номенклатуру об'ектів, які випускаються, без суттєвої модернізації самої системи.

Організаційною основою таких систем є груповий технологічний процес (групова технологія) на базі гнучких виробничих модулів (ГВМ) - функціонально та конструктивно закінчених структурних елементів ГВС, до складу яких входять верстати-автомати з ЧПУ, які переналагоджуються, та спеціальні засоби автоматизації прийому, орієнтації, транспортування ОВ тощо.
\end{abstract}

\section{Постановка задачі}

В технічній літературі можна зустріти різні підходи до групування OB.

Так, в [1] групування об'єктів здійснюеться з метою визначення груп технологічно однорідних об'ектів для їх спільної обробки в умовах групового виробництва. Процес групування виконуеться в два етапи: на першому - здійснюеться кодування об'ектів по конструктивно-технологічним ознакам; на другому - групування об'ектів з однаковими кодами або з кодами, що несуттево відрізняються.

Для групування об'єктів може також використовуватись система кодування по основних та додаткових ознаках [2].

В роботі [3] пропонуеться для групування об'ектів використовувати інтегральний показник, який об'єднуе трудоміскість та об’ем випуска об'єктів.

Пропонуеться також методика, яка базуеться на упорядкуванні номенклатури об'єктів в залежності від частоти їх появи в умовах виробництва [4].

(c) М.М. Ткач, М.М. Поліщук, 2005 
В ряді робіт $[5,6,1]$ пропонується здійснювати групування об’єктів на основі структурного підходу, який, насамперед, враховуе їх конструктивні особливості. Ці особливості визначають набори поверхонь та їх різні сполучення: плоскі поверхні, поверхні обертання, гвинтові та ін. Таким чином, в основу групування об'ектів покладені закони формування поверхонь.

В роботі [7] для групування об'ектів пропонуеться використовувати такі ознаки, як: склад робіт, послідовність їх виконання та необхідне для цього обладнання. При цьому метою групування служить забезпечення рівномірного завантаження обладнання, необхідного для обробки групи об'єктів.

Як показуе аналіз проведених робіт, існуючі підходи до групування об'єктів дуже об'ємні і мало полегшують роботу проектувальників ГВС, так як об'єм інформації для оперативного аналізу залишаеться дуже значним. Крім того, такі підходи не дають можливості забезпечити проектування таких ГВС, які без значних витрат можуть адаптуватися до зміни номенклатури ОВ.

Тому, з метою підвищення ефективності функціонування ГВС, виникає необхідність розробки нової методології формування групових операцій, яка не тільки дозволить об'єднувати технологічно однорідні об'єкти, але й забезпечить можливість деякої зміни номенклатури ОВ без модернізації самої системи.

\section{Формування групових операцій в умовах ГВС}

Запропонований підхід до формування групових операцій здійснюеться в декілька етапів: I етап - опис ОВ в термінах операцій технологічних процесів (ТП) їх виготовлення; II етап - побудова квадратичної матриці та попередне розбиття множини ОВ на групи; III етап - уточнення груп ОВ та формування групових операцій.

В загальному вигляді технологічний процес виготовлення $i$-го ОВ $o_{i} \in O$, де $O=\left\{o_{i}\right\}, i=[1, N]-$ множина ОВ для яких будується ГВС, може бути представлений наступним чином: $T_{i}=\left(\left\{O \Pi_{i_{m}}\right\} ; \Pi_{i}\right)$, де $\left\{O \Pi_{i_{m}}\right\}, m=[1, M]$ - набір операцій, реалізація яких забезпечуе отримання $i$-го ОВ; $\Pi_{i}, i=[1, N]$ - послідовність виконання цих операцій для $i$-го ОВ.

Таким чином, реалізація $i$ - го технологічного процесу $T_{i}$ забезпечуе отримання $i$ - го об'єкта $o_{i}$, тобто $T_{i} \Leftrightarrow o_{i}$. Тоді $i$ - й ОВ може бути представлений так: $o_{i}=\left(\left\{O \Pi_{i_{m}}\right\} ; \Pi_{i}\right)$.

В свою чергу, кожна операція $О_{i}$ технологічного процесу виготовлення $i$ - го ОВ може бути представлена як: $O \Pi_{i}=\left(B_{i_{k}} ; P_{i_{l}}\right)$, де $B_{i_{k}}$ - вид операції (наприклад: Т - токарна, С - свердлильна і т.д.); $P_{i_{l}}$ - параметри операції (програма для обладнання з ЧПУ, реалізація якої дозволить отримати той чи інший конструктивний елемент $i-$ го ОВ).

Тоді опис ОВ в термінах операцій ТП їх виготовлення буде мати наступний вигляд: $o_{i}=\left(\left\{\left(B_{i_{k}} ; P_{i_{l}}\right)_{m}\right\} ; \Pi_{i}\right)$. 
Наведений опис служить вихідною інформацією про ОВ для подальшого здійснення процесу формування групових операцій.

На основі даної інформації будуеться матриця (ОВ - операції ТП) розміром $[N * M]$ :

$$
A_{1}=\left|\begin{array}{l}
\left(\left\{\left(B_{1_{k}} ; P_{1_{l}}\right)_{m}\right\}, \Pi_{1}\right) \\
\cdots \\
\left(\left\{\left(B_{i_{k}} ; P_{i_{l}}\right)_{m}\right\}, \Pi_{i}\right) \\
\cdots \\
\left(\left\{\left(B_{N_{k}} ; P_{N_{l}}\right)_{m}\right\}, \Pi_{N}\right)
\end{array}\right|,
$$

де $N$ - кількість рядків, що відповідае числу ОВ, для яких будуеться ГВС, а $M$ - кількість стовпців, що відповідае числу операцій ТП, за допомогою яких здійснюеться виготовлення того чи іншого ОВ.

Аналіз даної матриці дозволяе визначити загальну кількість різнотипних операцій $K_{o}$, які повинна виконувати $Г В С$, та побудувати квадратичну матрицю $[N * N]$ :

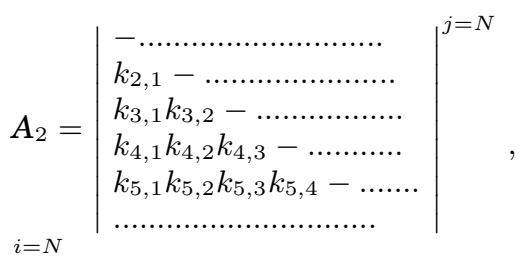

елементи якої визначаються за фрормулою: $K_{i j}=K_{o}-K_{H}$, причому $K_{H}-$ кількість не співпадаючих операцій для кожної пари ОВ матриці $A_{1}$.

Отримана квадратична матриця $A_{2}$ дозволяе зробити попередне розбиття множини об'ектів $O$ на групи. Для цього спочатку проводиться пошук максимального елемента $\max \left\{k_{i j}\right\}$ в матриці. Якщо таких елементів декілька, то довільним чином вибирається один з цих елементів. Після отримання такого елемента здійснюеться пошук по рядку та стовпцю, на перетині яких розташований цей елемент, елементів, рівних йому за значенням. При цьому можливі такі ситуації:

1. Якщо таких елементів більше не знайдено, то номери рядку та стовпця, на перетині яких знайдений цей елемент, заносяться до відповідної групи, і група закриваеться. Після чого викреслюються відповідний рядок і стовпчик з матриці;

2. Якщо такий елемент знайдено, то запам'ятовуеться номер рядку та стовпця, на перетині яких він розташований. Далі закінчуеться пошук для попереднього елемента: заносяться його координати до відповідної групи і викреслюеться відповідний рядок та стовпчик з матриці. Після цього до тієї ж групи заносяться координати елемента, який був запам'ятований, та виконуються відповідно нього всі попередні дії. Так продовжуеться, поки пошук для всіх запам'ятованих елементів не буде 
завершено і не закриеться чергова група ОВ.

Потім знов проводиться пошук максимального елемента $\max \left\{k_{i j}\right\}$ серед тих елементів матриці $A_{2}$, які ще залишились, і повторюються всі попередні операції.

Пошук завершуеться коли будуть викреслені всі рядки та стовпці.

Якщо після завершення пошуку залишається один елемент, то він заноситься у окрему групу.

Таким чином, побудована квадратична матриця $A_{2}$ дозволяе здійснити розбиття множини об‘ектів $O$ на групи $\Gamma p=\left\{\Gamma p_{j}\right\}, j=[1, J]$ в залежності від кількості співпадаючих операцій, але без врахування їх виду та параметрів.

3 метою врахування останніх, для кожної з отриманих груп ОВ формуеться групова операція: $\Gamma p_{j} \rightarrow \Gamma p O \Pi_{j}=\left\{O \Pi_{j_{p}}\right\}$, де $p=[1, P]-$ перелік різнотипних операцій для кожної групи ОВ.

Таким чином, формуеться деяка множина групових операцій $Г р О П=$ $\left\{\Gamma p O \Pi_{j}\right\}, j=[1, J]$, реалізацію яких повинна забезпечити ГВС, яка розробляеться.

Для уточнення груп ОВ сформовані групові операції ГрОП впорядковуються за ступенем зменшення в них кількості різнотипних операцій, а потім аналізуеться відношення другої групової операції $Г р О \Pi_{2}$ до першої $Г р О \Pi_{1}$. При цьому можливі наступні варіанти:

а) $\Gamma$ $О \Pi_{1} \supset \Gamma р O \Pi_{2}$, тоді ОВ другої групи приеднуються до ОВ першої групи, друга група ліквідуеться і здійснюеться перехід до розгляду наступної групової операції;

б) $Г р О \Pi_{1} \subset \Gamma р O \Pi_{2}$, тоді ОВ першої групи приєднуються до ОВ другої групи, яка стає першою, попередня перша група ліквідується і здійснюється перехід до розгляду наступної групової операції;

в) $Г р О \Pi_{2} \not \subset \Gamma p O \Pi_{1} ; \Gamma p O \Pi_{1} \not \subset \Gamma p O \Pi_{2}$, тоді розглядається відношення OB другої групи, представлених в термінах операцій ТП, до першої групової операції $Г р О \Pi_{1}$. Можливі дві ситуації: $Г р О \Pi_{1} \supset o_{1}=\left(\left\{O \Pi_{1_{m}}\right\} ; \Pi_{1}\right) \in$ $\Gamma p_{2}$, тоді об'ект $o_{1}$ залишає другу групу, приеднуеться до першої групи і здійснюється перехід до розгляду наступного обєекта даної групи; $o_{1} \not \subset Г р О \Pi_{1}$, тоді здійснюеться перехід до розгляду наступного обєекта даної групи.

Коли всі об‘екти даної групи розглянуті, відбуваеться перехід до розгляду наступної групової операції, відносно якої здійснюються всі попередні дії.

Процес уточнення груп ОВ закінчиться коли будуть розглянуті всі отримані на попередньому етапі групи ОВ та відповідні їм групові операціï.

\section{Висновки}

Наведена вище методологія формування групових операцій дозволяе не тільки мінімізувати кількість груп, на яку розбивається вихідна множина об‘ектів виробництва, але й формувати такі групові операції, які 
дозволять ГВС, що проектується на їх основі, без значних затрат адаптуватись до зміни номенклатури ОВ, оскільки вона проектуеться не під конкретну номенклатуру OB, а під деяку множину групових операцій, певний порядок реалізації яких дає можливість отримати той чи інший обєєкт.

\section{Літератера}

1. Митрофанов С.П. Групповая технология машиностроительного производства. - Л.: Машиностроение, 1983. - 779c.

2. Гибкие автоматизированные производственные системы/ Л.С. Ямпольский, О.М. Калин, М.М. Ткач и др.; Под ред. Л.С. Ямпольского.К.: Техніка, 1985.- 280c.

3. Васильев Д.В. Сабинин О.Ю. Ускоренное статистическое моделирование систем управления.- Л.: Энергоиздат, 1987.- 136с.

4. Коробецкий Ю.П. Моделирование объектов машиностроительных предприятий. - К.: УМК ВО, 1992.- 150с.

5. Автоматизация проектирования технологических процесов в машиностроении/ В.С. Корсаков, Н.М. Капустин, К.Х. Темпельгоф. Под общ. Ред. Н.М. Капустина.- М.: Машиностроение; Берлин: Техника, 1985.- 304c.

6. Лищинский Л.Ю. Структурный и параметрический синтез гибких производственных систем.- М.: Машиностроение, 1990.- 310с.

7. Коробецький Ю.П., Рамазанов С.К. Імітаційні моделі в гнучкому виробництві, Монографія.- Луганськ. Вид-во СНУ ім. В. Даля, 2003.280 c. 